\title{
TINJAUAN TENTANG SUBJEK HUKUM KORPORASI DAN FORMULASI PERTANGGUNGJAWABAN DALAM TINDAK PIDANA
}

\author{
Paulus Aluk Fajar Dwi Santo \\ Jurusan Hukum, Fakultas Humaniora, BINUS University \\ Jln. Kemanggisan Ilir III No. 45, Kemanggisan/Palmerah, Jakarta Barat 11480 \\ paulus_afds@binus.edu
}

\begin{abstract}
Article clarified corporate application as a law subject that had not been fully applied in Indonesia. Corporate status as a subject for criminal law only could be found in Criminal Law Legislation, out of KUHP that had been categorized as special criminal law, or administrative regulation having crime sanction. The research applied yuridis -normatif and yuridis comparative methods with the following results. There is incompleteness for the status of a corporate, when the corporate will be considered as a liable institution, how to show the liability, etc. The corporate liability in Indonesia in the special criminal law (outside KUHP), started with UU no. 7/Drt/1955 concerning Economy Criminal Act that later was continued by other special criminal law up to the affects that the corporate responsibility did not work in general, but it was only limited and applied to some special regulations out of those KUHP. Therefore, the design of Criminal Law Regulations that will be authorizeed into Law is supposed to be able to be guidance in overcoming corporate 's criminals
\end{abstract}

Keywords: corporate law, criminal law

\begin{abstract}
ABSTRAK
Artikel menjelaskan penerapan korporasi sebagai subjek hukum yang belum sepenuhnya diterapkan di Indonesia. Pengaturan korporasi sebagai subjek hukum pidana hanya dapat ditemukan dalam perundangundangan hukum pidana di luar KUHP yang dikategorikan sebagai tindak pidana khusus, ataupun perundangundangan administrasi yang bersanksi pidana. Dari hasil penelitian yang menggunakan pendekatan yuridisnormatif dan dilengkapi dengan pendekatan yuridis- komparatif terlihat ketidaktuntatasan dalam merumuskan korporasi sebagai subyek hukum yang dapat dijatuhi pidana. Adapun ketidaktuntasan tersebut yaitu mengenai kapan suatu korporasi dianggap harus bertanggung jawab, ataupun bagaimana cara pertanggungjawabannya. Prinsip pertanggungjawaban korporasi (corporate liability) di Indonesia yang tersebar dalam hukum pidana khusus (di luar KUHP), yang diawali dengan UU No 7/Drt/1955 tentang Tindak Pidana Ekonomi yang kemudian disusul oleh peraturan pidana khusus lain yang menjadikan kebijakan formulasi pertanggungjawaban korporasi yang menyangkut subjek tindak pidana korporasi tidak berlaku secara umum, tetapi terbatas dan hanya berlaku terhadap beberapa perundang-undangan khusus di luar KUHP tersebut, untuk itu, kedepan Rancangan Kitab Undang-Undang Hukum Pidana yang akan segera disahkan menjadi Undang-undang harus mampu menjadi pedoman dalam menangani kejahatan yang dilakukan oleh korporasi.
\end{abstract}

Kata kunci: hukum korporasi, hukum pidana 


\section{PENDAHULUAN}

Bahasan tentang korporasi sudah tidak asing lagi bagi kita, bahkan akhir-akhir ini seringkali kita mendengar tentang strategi korporasi baik itu merger, akuisisi, konsolidasi, perencanaan perpajakan dan lai-lain. Korporasi banyak memberikan kontribusi perkembangan suatu negara, terutama dalam bidang ekonomi, misalnya pemasukan negara dalam bentuk pajak maupun devisa, sehingga dampak korporasi tampak sangat positif. Namun di sisi lain, korporasi juga tak jarang menciptakan dampak negatif, seperti pencemaran, pengurasan sumber daya alam, persaingan secara curang, manipulasi pajak, eksploitasi terhadap buruh, menghasilkan produk-produk yang membahayakan pemakainya, serta penipuan terhadap konsumen. Korporasi dapat meningkatkan kekayaan negara dan tenaga kerja, namun revolusi struktur ekonomi dan politik telah menumbuhkan kekuatan korporasi yang besar, sehingga negara terlalu tergantung korporasi sehingga negara dapat didikte sesuai kepentingannya. Perusahaan-perusahaan raksasa bukan saja memiliki kekayaan yang demikian besarnya, tetapi juga memiliki kekuatan sosial dan politis sedemikian rupa sehingga operasi atau kegiatan perusahaan-perusahaan tersebut sangat mempengaruhi kehidupan setiap orang sejak mulai lahir sampai matinya. Kehidupan kerja serta kesehatan dan keamanan dari sebagian besar penduduk dikendalikan baik secara langsung atau tidak langsung oleh perusahaan-perusahaan besar ini. Telah terbukti bahwa perusahaan-perusahan multinasional (multinational) telah menjalankan pengaruh politik baik terhadap pemerintah di dalam negeri maupun di luar negeri di mana perusahaan itu beroperasi.

Tujuan korporasi untuk terus meningkatkan keuntungan yang diperolehnya mengakibatkan sering terjadinya tindakan pelanggaran hukum. Korporasi baik itu berupa suatu badan hukum maupun bukan memiliki kekuasaan yang besar dalam menjalankan aktvitasnya sehingga sering melakukan aktivitas yang bertentangan dengan ketentuan hukum yang berlaku, bahkan memunculkan korban yang menderita kerugian. Walaupun demikian, banyak korporasi yang lolos dari kejaran hukum sehingga tindakan korporasi yang bertentangan dengan hukum tersebut semakin meluas dan sulit dikontrol. Dengan mudahnya korporasi menghilangkan bukti-bukti kejahatannya terhadaap masyarakat termasuk juga mengintervensi para aparat penegak hukum. Kasus kejahatan korporasi di Indonesia yang pernah mencuat ke-permukaan adalah kasus biskuit beracun pada tahun 1989 yang mengakibatkan sekitar 13 orang meninggal, pelangaran oleh korporasi berkaitan dengan pelanggaran batas maksimal pemberian kredit bagi kelompok usaha dibidang perbankan, pencemaran lingkungan, iklan yang menyesatkan, mark up, merupakan bagian dari bisnis sehari-hari.

Peristiwa besar yang lain adalah munculnya sumber lumpur di Sidoarjo yang diidentifikasi disebabkan oleh kegiatan pengeboran yang tidak memenuhi standar dilakukan oleh PT Lapindo Brantas, dampak kejadian tersebut menjadikan ribuan orang kehilangan tempat tinggal akibat terendam lumpur, dan juga industri-indust ri disekitar semburan lumpur yang harus ditutup akibat tidak berproduksi yang mengakibatkan ribuan orang kehilangan pekerjaannya kemudian disusul kasus Gayus Tambunan tentang pajak, seperti yang telah diberitakan oleh berbagai media dan mencuat ketika disebutkan oleh mantan Kabareskrim Komjen Susno Duadji sebagai seseorang yang berkaitan erat dengan makelar kasus. Susno menyebutkan Gayus memiliki Rp 25 miliar di rekeningnya, dimana pada dasarnya untuk bisa mengungkapkan kasus Gayus bisa dimulai dari siapa atau perusahaan apa saja yang keberatan pajaknya, ditangani oleh Gayus yang jumlahnya cukup banyak yaitu sekitar 140 perusahaan.

Kerugian yang di timbulkan kejahatan korporasi dapat bersifat fisik, ekonomi dan biaya sosial. Kecelakaan tenaga kerja merupakan salah satu konsekuensi yang bersifat fisik. Sedangkan kasus biskuit beracun yang menimbulkan korban merupakan contoh hasil produksi suatu korporasi yang tidak aman bagi konsumen, yang sering disebut kelalaian korporsi. Konsekuensi yang bersifat ekonomis tidak diragukan lagi, mengingat profit merupakan motifasi utama terjadinya kejahatan korporasi. Sedangkan yang paling mengancam dan menakutkan yang dianggap kerugian sosial yang 
timbul karena kejahatan korporasi, adalah dampak merusak terhadap standar moral dari masyarakat bisnis.

Permasalahan korporasi sebagai subjek hukum pidana tidak lepas dari aspek hukum perdata. Dalam hukum perdata orang perseorangan bukanlah satu- satunya subjek hukum. Hal ini disebabkan masih ada subjek hukum lain yang memiliki hak dan dapat melakukan perbuatan hukum sama seperti orang perseorangan. Pandangan seperti ini berbeda dengan KUHP yang hanya mengenal orang perseorangan sebagai subjek hukum.

Kitab Undang-Undang Hukum Pidana (KUHP) yang berlaku di Indonesia saat ini merupakan produk hukum Belanda yang diberlakukan berdasarkan asas konkordansi di wilayah Hindia Belanda. Subjek tindak pidana yang dikenal dalam KUHP adalah orang perorangan. Dengan kata lain, hanya manusia yang dapat melakukan tindak pidana dan hanya manusia yang dapat dituntut serta dibebani pertanggungjawaban pidana. KUHP tidak mengenal korporasi sebagai subjek hukum pidana. Hal ini didasarkan pada Pasal 59 KUHP, dimana apabila korporasi yang melakukan tindak pidana, maka pertanggungjawaban pidana dibebankan kepada pengurus korporasi dalam hal pengurus korporasi melakukan tindak pidana dalam rangka mewakili atau dilakukan atas nama korporasi tersebut. Dalam perkembangannya, korporasi (juridical person) muncul sebagai subjek yang dapat melakukan tindak pidana dan seharusnya pula dapat dipertanggungjawabkan dalam hukum pidana, namun sayangnya kondisi ini belum diwujudkan secara konkrit dalam KUHPidana kita, Berdasarkan hal-hal tersebut di atas dihubungkan dengan latar belakang masalah, maka masalah yang diangkat dalam penelitian ini adalah: (1) bagaimana konsepsi hukum positif Indonesia terhadap subyek hukum korporasi; (2) bagaimana formulasi pertanggungjawaban korporasi dalam tindak pidana.

Berdasarkan latar belakang masalah dan permasalahan yang telah dikemukakan di atas, maka tujuan penelitian ini adalah; untuk mengkaji/menganalisis perlakuan hukum positif terhadap kejahatan korporasi serta mendapatkan formula secara selekif untuk pengenaan sanksi terhadap kejahatan yang dilakukan korporasi.

Kegunaan penelitian ini diharapkan dapat memberikan manfaat atau kegunaan baik yang bersifat praktis maupun teoritis, dari segi praktis hasil penelitian ini diharapkan dapat memberikan pemikiran bagi pembuat kebijakan dalam memformulasikan pertanggungjawaban pidana korporasi serta formulasi sanksi pidananya dalam hal korporasi melakukan tindak pidana dan diharapkan juga hasil penelitian ini dapat memberikan sumbangan yang berarti bagi aparat penegak hukum dalam menjalankan tugasnya menegakkan hukum. Dari segi teoritis, hasil penelitian ini diharapkan dapat menambah pemahaman di bidang akademik, di bidang ilmu hukum khususnya hukum pidana di bidang tindak pidana korupsi.

\section{METODE}

Permasalahan pokok dalam penelitian ini merupakan masalah kebijakan, yaitu masalah kebijakan hukum pidana dalam mengatur tentang aturan pemidanaan (pertanggungjawaban pidana) korporasi dalam tindak pidana korupsi yang tidak dapat dipisahkan dari sanksi pidana yang dapat dijatuhkan pada korporasi. Oleh karena itu pendekatan terhadap masalah ini adalah pendekatan yang berorientasi pada kebijakan. Namun mengingat sasaran utama penelitian ini adalah kebijakan legislatif dalam merumuskan pertanggungjawaban pidana korporasi dalam tindak pidana korupsi maka pendekatan terutama ditempuh dengan pendekatan yuridis normatif. Pendekatan yuridis-normatif dapat juga digunakan bersama-sama dengan metode pendekatan lain, dengan demikian penelitian ini ditunjang dan dilengkapi pula dengan, pendekatan yuridis- komparatif 


\section{HASIL DAN PEMBAHASAN}

\section{Konsepsi Hukum Positif Indonesia terhadap Subyek Hukum Korporasi}

Pertama-tama jika membicarakan tentang korporasi, maka yang terlintas dalam pikiran kita korporasi ini adalah sebagai subjek hukum buatan manusia yang mulai keberadaannya dan kematiannya ditentukan oleh putusan hukum, kalau kita menilik kebelakang pengertian korporasi tidak bisa dilepaskan dari bidang hukum perdata. Hal ini disebabkan oleh istilah korporasi erat kaitannya dengan istilah badan hukum yang dikenal dalam bidang hukum perdata.

Hukum tidak hanya mengatur orang perseorangan sebagai subjek hukum, akan tetapi subjek hukum selain orang perseorangan. Subjek hukum yang dimaksud adalah badan hukum (rechtspersoon), yang padanya melekat hak dan kewajiban hukum layaknya orang perseorangan sebagai subjek hukum. Secara etimologis, pengertian korporasi yang dalam istilah lain dikenal dengan corporatie (Belanda), corporation (Inggris), korporation (Jerman), berasal dari bahasa latin yaitu corporatio. Corporatio sebagai kata benda (subatantivum) berasal dari kata kerja coporare yang banyak dipakai orang pada jaman abad pertengahan atau sesudah itu. Corporare sendiri berasal dari kata corpus (badan), yang berarti memberikan badan atau membadankan. Dengan demikian, maka akhirnya corporatio itu berarti hasil dari pekerjaan membadankan, dengan kata lain badan yang dijadikan orang, badan yang diperoleh dengan perbuatan manusia sebagai lawan terhadap badan manusia, yang terjadi menurut alam.

Hukum tidak hanya memikirkan manusia sebagai subjek dalam hukum, tetapi juga subjek bukan orang. Hukum lalu menciptakan badan hukum (korporasi) yang memiliki hak dan kewajiban layaknya orang perseorangan. Hal ini dikarenakan perkembangan masyarakat yang ikut berpengaruh dalam berkembangnya kejahatan, salah satunya dengan munculnya kejahatan korporasi.

Kejahatan yang dilakukan korporasi lebih sulit untuk diidentifikasi karena kompleksitas dari korporasi itu sendiri. Menurut Rahardjo, Badan yang diciptakannya itu terdiri dari corpus, yaitu struktur fisiknya dan ke dalamnya hukum memasukkan unsur animus yang membuat badan itu mempunyai kepribadian. Oleh karena badan hukum ini merupakan ciptaan hukum, maka kecuali penciptaannya, kematiannya pun ditentukan oleh hukum, korporasi dapat bertindak seperti manusia pada umumnya, hanya saja, perihal yang menyangkut korporasi seperti hak, kewajiban, serta tanggungjawabnya diatur oleh hukum. Dengan diaturnya korporasi sebagai subjek hukum maka diharapkan korporasi yang melakukan kejahatan tersebut dapat dipertangunggjawabkan secara hukum.

Ada beberapa definisi yang dikemukakan mengenai korporasi. Menurut Sjahdeini (2007), korporasi dapat dilihat dari artinya yang sempit, maupun artinya yang luas. Kemudian Sutan Remi Sjahdeini mengungkapkan bahwa menurut artinya yang sempit, yaitu sebagai badan hukum, korporasi merupakan figur hukum yang eksistensi dan kewenangannya untuk dapat atau berwenang melakukan perbuatan hukum diakui oleh hukum perdata. Artinya, hukum perdatalah yang mengakui eksistensi korporasi dan memberikannya hidup untuk dapat berwenang melakukan perbuatan hukum sebagai suatu figur hukum. Demikian juga halnya dengan matinya korporasi. Suatu korporasi hanya mati secara hukum apabila matinya korporasi itu diakui oleh hukum.

Lebih lanjut, Sjahdeini (2007) mengemukakan pengertian korporasi dalam arti yang luas dapat dilihat dari pengertian korporasi dalam hukum pidana. Menurutnya, dalam hukum pidana, korporasi meliputi baik badan hukum maupun bukan badan hukum. Bukan saja badan-badan hukum seperti perseroan terbatas, yayasan, koperasi atau perkumpulan yang telah disahkan sebagai badan hukum yang digolongkan sebagai korporasi menurut hukum pidana, tetapi juga firma, persekutuan komanditer atau CV, dan persekutuan atau maatschap, yaitu badan-badan usaha yang menurut hukum 
perdata bukan suatu badan hukum. Dari uraian tersebut, dapat dilihat bahwa ada perbedaan pengertian korporasi dalam bidang hukum perdata dengan pengertian korporasi dalam bidang hukum pidana. Dalam bidang hukum perdata, yang dimaksud dengan korporasi adalah badan hukum, sedangkan dalam bidang hukum pidana yang dimaksud dengan korporasi bukan hanya badan hukum saja, tetapi juga yang bukan badan hukum.

Definisi korporasi menurut Solomon dan Palmiter, adalah: "A corporation is a structuring device for conducting modern business. It is a framework - a legal person - through which a business can enter into contracts, own property, sue in court, and be sued. It is taxable entity subject property, sales, income, and other taxes. It can range in size from a one person business to a multinational conglomerate. It is a capitalist invention for the pooling of capital (from shareholders and lenders), management (from executives), and other factors of production (from suppliers and employees). It is a creature of state law; its formation and existence depend on state enabling statutes. A "corporation is an artifice. Nobody has ever seen one. A business conducted as a corporation looks much the same as one conducted in a non corporate form. In the end, a corporation is a construct of the law - a set of legal relationships. It is what the law defines to be."

Berdasarkan definisi korporasi yang dikemukakan di atas, terlihat bahwa korporasi hakikatnya adalah hasil konstruksi atau ciptaan hukum yang menghendaki agar korporasi mempunyai status sebagi subjek hukum yang mempunyai hak dan kewajiban yang diatur menurut undang-undang, termasuk juga pertanggungjawaban korporasi jika melakukan kejahatan. Mengenai pengertian korporasi, Prasetyo mengemukakan bahwa kata korporasi sebutan yang lazim dipergunakan di kalangan pakar hukum pidana untuk menyebut apa yang biasa dalam bidang hukum lain, khususnya bidang hukum perdata, sebagai badan hukum, atau yang dalam bahasa Belanda di sebut sebagai rechtspersoon, atau yang dalam bahasa Inggris disebut legal entities atau corporation.

Ali juga mengemukakan pendapatnya mengenai pengertian korporasi dengan menyatakan pendapatnya bahwa hukum memberi kemungkinan dengan memenuhi syarat-syarat tertentu, bahwa suatu perkumpulan atau badan lain dianggap sebagai orang yang merupakan pembawa hak, dan karenanya dapat menjalankan hak-hak seperti orang biasa serta dapat dipertanggunggugatkan. Namun demikian, badan hukum (korporasi) bertindak harus dengan perantara orang biasa. Akan tetapi, orang yang bertindak itu tidak untuk dirinya sendiri, melainkan untuk dan atas pertanggungjawaban korporasi. Dari aspek hukum perdata, hukum mengenal ada dua macam subjek hukum yaitu orang perseorangan dan badan hukum, sedangkan hukum pidana khususnya KUHP, hanya mengenal orang perseorangan. Tetapi untuk undang-undang khusus di luar KUHP mengenal adanya korporasi sebagai subjek hukum, baik itu berupa badan hukum maupun bukan badan hukum. Senada dengan pendapat diatas, Setiyono (2003) mengemukakan bahwa korporasi merupakan istilah yang biasa digunakan oleh para ahli hukum pidana dan kriminologi untuk menyebut badan hukum (rechtspersoon), legal body atau legal person. Konsep badan hukum itu sebenarnya bermula dari konsep hukum perdata yang tumbuh akibat dari perkembangan masyarakat.

Pengertian korporasi dalam hukum pidana Indonesia lebih luas dari pengertian badan hukum sebagaimana dalam konsep hukum perdata. Dalam berbagai peraturan perundang-undangan hukum pidana Indonesia dinyatakan bahwa pengertian korporasi adalah kumpulan terorganisasi dari orang dan atau kekayaan baik merupakan badan hukum maupun bukan. Dari pendapat di atas terlihat bahwa ada perbedaan pandangan mengenai subjek hukum, yaitu korporasi sebagai subjek hukum bidang hukum perdata dengan korporasi sebagai subjek hukum dalam bidang hukum pidana. Pengertian korporasi dalam bidang hukum perdata adalah badan hukum, sedangkan dalam hukum pidana pengertian korporasi bukan hanya yang berbadan hukum, tetapi juga yang tidak berbadan hukum. Mengenai pengertian korporasi dalam bidang hukum pidana yang lebih luas dibandingkan dengan pengertian korporasi dalam bidang hukum perdata, Priyatno berpendapat bahwa pengertian/perumusan korporasi dalam hukum perdata ternyata dibatasi, sebagai badan hukum. Sedangkan apabila ditelaah lebih lanjut, pengertian/perumusan korporasi dalam hukum pidana ternyata lebih luas. 
Di Indonesia, perkembangan korporasi sebagai subjek tindak pidana terjadi di luar KUHP, dalam perundang-undanga khusus. Sedangkan KUHP sendiri masih tetap menganut subjek tindak pidana berupa orang. Ada persamaan antara dua pendapat terakhir yang mengemukakan bahwa pengertian korporasi sebagai subjek hukum dalam hukum pidana lebih luas dibandingkan dengan pengertian korporasi sebagai subjek hukum dalam hukum perdata. Hal ini didasarkan pada pengaturan korporasi sebagai subjek tindak pidana dalam peraturan perundang-undangan khusus di luar KUHP.

Pengaturan korporasi sebagai subjek tindak pidana terdapat dalam peraturan perundangundangan khusus di luar KUHP, antara lain:

a. Undang-Undang Nomor 7 Drt 1955 tentang Tindak Pidana Ekonomi. Dalam Pasal 15 ayat (1) disebutkan bahwa: "Jika suatu tindak pidana ekonomi dilakukan atas nama suatu badan hukum, suatu perseroan, suatu perserikatan, orang atau yayasan, maka...”

b. Undang-Undang Nomor 5 Tahun 1984 tentang Perindustrian. Penyebutan korporasi tidak secara tertulis, akan tetapi dalam Pasal 21 ayat (1) Jo. Pasal 1 angka 7 disebut subjek tindak pidana berupa "Perusahaan Industri”. Dalam Pasal 1 angka 7 dijelaskan: "Perusahaan industri adalah badan usaha yang melakukan kegiatan di bidang usaha industri."

c. Undang-Undang Nomor 6 Tahun 1984 tentang Pos. Dalam Pasal 19 ayat (3) disebutkan: “...dilakukan oleh, atau atas nama, suatu badan hukum perseroan, perserikatan orang lain atau yayasan,...”

d. Undang-Undang Nomor 9 Tahun 1985 Tentang Perikanan sebagaimana yang telah diubah dengan Undang-Undang Nomor 31 Tahun 2004. Dimana menurut Pasal 6 ayat (1), Pasal 7 ayat (1) Jo. Pasal 24, Pasal 10 ayat (1) Jo. Pasal 25, "Setiap orang atau badan hukum dilarang melakukan..."

e. Undang-Undang Nomor 7 Tahun 1992 tentang Perbankan sebagaimana yang telah diubah dengan Undang-Undang Nomor 10Tahun 1998. Menurut Pasal 46 ayat (2) bahwa, “...dilakukan oleh badan hukum yang berbentuk Perseroan Terbatas, perserikatan, yayasan atau korporasi.”

f. Undang-Undang Nomor 8 Tahun 1995 tentang Pasar Modal. Subjek yang disebut dalam formulasi delik adalah "setiap pihak". Yang dimaksud dengan setiap pihak menurut Pasal 1 angka 23 adalah: "Orang perorangan, perusahaan, usaha bersama, asosiasi atau kelompok yang terorganisasi."

g. Undang-Undang Nomor 5 Tahun 1997 tentang Psikotropika. Dalam formulasi tindak pidana psikotropika, hanya disebut dengan istilah "korporasi”. Sedangkan pengertian korporasi dijelaskan dalam Pasal 1 angka 13, yaitu "kumpulan terorganisasi dari orang dan/atau kekayaan, baik merupakan badan hukum maupun bukan.” Undang-undang inilah yang pertama menggunakan istilah korporasi.

h. Undang-Undang Nomor 22 Tahun 1997 tentang Narkotika. Disebut juga dengan korporasi seperti halnya pada undang-undang psikotropika. Pengertian korporasi dirumuskan dalam Pasal 1 angka 19, yaitu "kumpulan terorganisasi dari orang dan/atau kekayaan, baik merupakan badan hukum maupun bukan.”

i. Undang-Undang Nomor 23 Tahun 1997 tentang Pengelolaan Lingkungan Hidup. Menurut Pasal 46 ayat (1), ditentukan “...jika dilakukan oleh atau atas nama suatu badan hukum, perseroan, perserikatan, yayasan atau organisasi lain.”

j. Undang-Undang Nomor 5 Tahun 1999 tentang Larangan Praktek Monopoli dan Persaingan Usaha Tidak Sehat. Formulasi delik dalam undang-undang ini hanya diatur dalam Pasal 48 saja, yang terdiri dari pelanggaran beberapa pasal dalam undang-undang ini. Dalam pasal-pasalyang disebut di dalam Pasal 48 tersebut, tidak ada penyebutan korporasi atau badan hukum. Subjek yang disebut adalah "pelaku usaha". Dalam ketentuan umum Pasal 1 sub 5 dijelaskan bahwa: "pelaku usaha adalah setiap orang perorangan atau badan usaha, baik berbentuk badan hukum atau bukan."

k. Undang-Undang Nomor 8 Tahun 1999 tentang Perlindungan Konsumen. Subjek tindak pidana yang disebut dalam formulasi delik adalah pelaku usaha dalam Pasal 62. Pengertian pelaku usaha dijelaskan dalam Pasal 1 angka 3, yaitu: "pelaku usaha adalah setiap orang perorangan atau badan usaha, baik yang berbadan hukum maupun yang bukan”, sama dengan rumusan dalam UndangUndang Nomor 5 Tahun 1999.

l. Undang-Undang Nomor 31 Tahun 1999 tentang Pemberantasan Tindak Pidana Korupsi sebagaimana telah diubah dengan Undang-Undang Nomor 20 Tahun 2001. Perumusannya: “...jika 
dilakukan oleh korporasi. Pengertiannya dijelaskan dalam Pasal 1 angka 1, yaitu: "Korporasi adalah kumpulan terorganisasi dari orang dan atau kekayaan, baik merupakan badan hukum maupun bukan badan hukum.”

m. Undang-Undang Nomor 21 Tahun 2001 tentang Minyak dan Gas Bumi. Istilah yang digunakan adalah badan usaha. Pengertian badan usaha diatur dalam Pasal 1 angka 17 yang menyatakan: "Badan usaha adalah perusahaan berbentuk badan hukum yang menjalankan jenis usaha bersifat tetap, terus-menerus dan didirikan sesuai dengan peraturan perundang-undangan yang berlaku serta bekerja dan berkedudukan dalam wilayah Negara Kesatuan Republik Indonesia.”

n. Undang-Undang Nomor 8 Tahun 2010 tentang Pencegahan Dan Pemberantasan Tindak Pidana Pencucian Uang. Istilah yang dipakai adalah korporasi. Pengertiannya dijelaskan dalam Pasal 1 angka 10 yaitu: "kumpulan terorganisasi dari orang dan/atau kekayaan, baik merupakan badan hukum maupun bukan badan hukum.”

Dari berbagai peraturan di atas yang merumuskan korporasi sebagai subjek tindak pidana dalam perundang-undangan, dapat dilihat bahwa pengaturan korporasi sebagai subjek tindak pidana terdapat dalam undang-undang khusus di luar KUHP. Selain itu juga, peraturan perundang-undangan tersebut menunjukkan bahwa pengertian korporasi dalam bidang hukum pidana lebih luas daripada pengertian korporasi dalam bidang hukum perdata.

Arief (1998) mengemukakan bahwa, dari perumusan korporasi sebagai subjek tindak pidana yang terdapat dalam undang-undang khusus di luar KUHP dapat disimpulkan bahwa: (1) penentuan korporasi sebagai subjek tindak pidana hanya untuk tindak pidana tertentu, yang diatur dalam undangundang khusus; (2) pada awalnya tidak digunakan istilah "korporasi", tetapi digunakan istilah yang bermacam-macam (tidak seragam) dan tidak konsisten; (3) istilah "korporasi" mulai terlihat pada tahun 1997 dalam Undang- Undang Psikotropika yang dipengaruhi oleh istilah dalam Konsep KUHP 1993.

Berkaitan dengan pengertian korporasi, Konsep KUHP 2006 juga mengatur mengenai korporasi sebagai subjek tindak pidana yang diatur dalam Pasal 47 Konsep KUHP. Konsep KUHP 2006 juga memberikan pengertian korporasi dalam Pasal 182, yaitu: "Korporasi adalah kumpulan terorganisasi dari orang dan/atau kekayaan, baik yang merupakan badan hukum maupun bukan badan hukum”. Dengan diaturnya korporasi sebagai subjek tindak pidana dalam Konsep KUHP, maka diharapkan kelak aturan tersebut dapat menjadi pedoman bagi pengaturan korporasi sebagai subjek tindak pidana dalam peraturan perundang-undangan di luar KUHP.

Menurut pendapat penulis, definisi yang diusulkan pada Konsep KUHP 2006 ini sudah tepat, namun perlu ada penjabaran lebih lanjut terutama terkait dengan kumpulan terorganisasi, dimana pengertian ini bisa juga menjerat institusi pemerintah. Misalnya, jika itu berkaitan dengan penyelewengan dibidang pajak, andaikata perbuatan ini tidak ada penjagaan secara sistem dan sudah dilakukan berkali-kali oleh pegawainya atau bahkan dilakukan secara sistematis dan diketahui oleh atasannya, kondisi ini subyek pelakunya harus dikategorikan sebagai subyek kejahatan korporasi. Aspek kejahatan terorganisir, yang dalam literatur mendapat tempat dalam klasifikasi tersendiri, tapi sebenarnya dalam pengertian yang lebih luas adalah merupakan bagian dari kejahatan korporasi, korporasi adalah suatu organisasi, suatu bentuk organisasi dengan tujuan tertentu yang bergerak dalam bidang ekonomi atau bisnis, maka kita harus melihat kejahatan korporasi sebagai kejahatan yang bersifat organisatoris, yaitu suatu kejahatan yang terjadi dalam konteks hubungan-hubungan yang kompleks dan harapan-harapan diantara dewan direksi, eksekutif dan manejer disuatu pihak dan diantara kantor pusat, bagian-bagian dan cabang-cabang pada pihak lain.

Berdasarkan pengertian seperti yang dimaksud di atas, korporasi tidak lagi hanya berkaitan dengan badan hukum atau badan usaha, tetapi juga berkaitan dengan suatu bentuk organisasi baik itu swasta maupun pemerintah. Jadi kejahatan yang terjadi di bidang pajak, di bidang tenaga kerja, di 
bidang lingkunga dan dibidang-bidang lain yang diorganisir oleh institusi pemerintah bisa dimintakan pertanggunjawabannya sampai dengan tingkat korporasi.

\section{Formulasi Pertanggungjawaban Tindak Pidana yang Dilakukan oleh Korporasi}

Seiring dengan perkembangan masyarakat, dirasa sangat perlu untuk menempatkan korporasi sebagai subjek tindak pidana agar dapat dibebani pertanggungjawaban pidana apabila melakukan kejahatan, sehingga korporasi dalam menjalankan usahanya tidak melakukan tindakan-tindakan yang melanggar ketentuan hukum dan merugikan masyarakat umum. Hukuman atas segala kejahatan korporasi adalah sebuah persoalan politis. Yang terjadi dalam peristiwa politis adalah tawar-menawar yang mencari keseimbangan antara hak dan kewajiban warga negara. Dalam hitungan hak dan kewajiban, korporasi dibolehkan menikmati hak-hak yang sangat luas dan menciutkan kewajibankewajiban mereka.

Kerugian akibat kejahatan korporasi sering sulit dihitung karena akibat yang ditimbulkannya berlipat-lipat, sementara hukuman atau denda pengadilan acap kali tidak mencerminkan tingkat kejahatan mereka Perusahaan memiliki kekuatan untuk menentukan kebijakan melalui direktur dan para eksekutif dan perusahaan seharusnya bertanggung jawab atas akibat dari kebijakan mereka. Namun perusahaan-tidak seperti manusia—tidak dibebani oleh berbagai emosi dan perasaan sehingga dengan mudahnya dapat menutupi perilaku buruknya.

Terdapat dua model kejahatan korporasi. Pertama, kejahatan yang dilakukan oleh orang yang bekerja atau yang berhubungan dengan suatu perusahaan yang dipersalahkan. Kedua, perusahaan sendiri yang melakukan tindakan kejahatan melalui karyawan-karyawannya. Kejahatan yang terjadi dalam konteks bisnis dilatar belakangi oleh berbagai sebab. Human error yang dipadukan dengan kebijakan yang sesat dan kekeliruan dalam pengambilan keputusan merangsang terjadinya tindakan pelanggaran hukum. Pada pendekatan di Amerika mengenai vicarious liability menyatakan bahwa bila seorang pegawai korporasi atau agen yang berhubungan dengan korporasi, bertindak dalam lingkup pekerjaannya dan dengan maksud untuk menguntungkan korporasi dengan melakukan suatu kejahatan, tanggung jawab pidananya dapat dibebankan kepada perusahaan. Tidak peduli apakah perusahaan secara nyata memperoleh keuntungan atau tidak atau apakah perusahaan telah melarang aktivitas tersebut atau tidak.

Sedangkan di Inggris, vicarious liability terbatas pada tanggung jawab perusahaan terhadap kejahatan korporasi yang dilakukan oleh seorang yang memiliki kekuasaan yang tinggi (identification). Teori ini menyatakan bahwa korporasi tidak dapat melakukan sesuatu kecuali melalui seorang yang dapat mewakilinya. Bila seorang yang cukup berkuasa dalam struktur korporasi, atau dapat mewakili korporasi melakukan suatu kejahatan, maka perbuatan dan niat orang itu dapat dihubungkan dengan korporasi. Korporasi dapat dimintai pertanggungjawaban secara langsung. Namun, suatu korporasi tidak dapat disalahkan atas suatu kejahatan yang dilakukan oleh seorang yang berada di level yang rendah dalam hirarki korporasi tersebut. Komisi Hukum Inggris telah mengusulkan bahwa terdapat satu kejahatan baru, yaitu pembunuhan oleh korporasi corporate killing. Kejahatan ini merupakan suatu spesies terpisah dari manslaugter yang hanya dapat dilakukan oleh korporasi. Dalam hal ini, masalah-masalah yang berkaitan dengan penegasan tentang kesalahan korporasi, seperti pembuktian dari niat atau kesembronoan, dapat diatasi dengan membuat definisi khusus yang hanya dapat diterapkan kepada korporasi. Pada era globalisasi ini, perkembangan perusahaan multinasional sangat pesat, bahkan perusahaan tersebut mampu menempatkan diri pada posisi yang sangat strategis untuk memperoleh perlindungan hukum sehingga peradilan dalam negeri sulit untuk mengajukan tuntutan terhadap tindakan mereka yang merugikan. Agar kelemahan perangkat hukum tidak terulang lagi, perlu dibuat aturan pertanggung jawaban korporasi yang komprehensif dan mencakup semua kejahatan. Namun, pada pengadilan atas tindakan kriminalirtas korporasi, keputusan mengenai hukuman dan sanksi, selalu menjadi hal terakhir untuk diputuskan. 
Setiap tuntuan yang terjadi atas kejahatan korporasi selalu dipersulit sehingga sering tidak dapat direalisasikan. Dengan demikian dapat terlihat bahwa hukum pun masih tidak dapat diandalkan untuk menindak lanjuti masalah kejahatan korporasi. Suatu tindakan kejahatan, terjadi karena korporasi tersebut mendapatkan keuntungan dari tindakan kejahatan yang dilakukannya. Oleh karena itu, agar dapat menghapuskan tindakan kejahatan korporasi, dapat dilakukan dengan mengambil keuntungan yang diperolehnya atas tindakan kriminalitas tersebut. Misalnya, dengan membebankan korporasi suatu denda yang lebih besar dibandingkan dengan keuntungan yang diperoleh. Jika tindakan kriminalitas tidak lagi mengutungkan korporasi, maka ia tidak akan terlibat kembali dalam suatu tindakan kriminal. Namun dalam prakteknya, denda hukum yang dijatuhkan kepada korporasi sekedar dihitung sebagai biaya produksi tanpa sepeserpun mengurangi keuntungan korporasi. Walaupun mengurangi keuntungan, praktek illegal korporasi masih dapat terus berlanjut. Dengan kata lain, denda yang dikenakan kepada korporasi hanya mengubah tindakan kejahatan korporasi dari kesalahan terhadap masyarakat menjadi biaya dalam kegiatan bisnis Publisitas atas keburukan korporasi juga dapat dilakukan sebagai sanksi atas kejahatan korporasi. Namun sayangnya, hal tersebut membawa dampak yang tidak diinginkan.

Jika terjadi pemboikotan dari seluruh konsumen terhadap semua produk korporasi, maka secara pidana, pengadilan berhasil mengadili korporasi tersebut. Tetapi jika korporasi mengalami kerugiam yang besar, maka korporasi akan mengurangi jumlah karyawannya sehingga akan banyak pekerja yang kehilangan pekerjaannya. Beraneka ragam sanksi yang dikenakan kepada korporasi seperti melalui denda, kompensasi dan ganti rugi, kerja sosial, pengenaan perbaikan, publisitas keburukan, dan orientasi pengendalian, tidak dapat menghentikan tindakan kejahatan yang dilakukan korporasi. Korporasi dapat lolos dari sanksi-sanksi tersebut dengan mengorbankan pegawai mereka. Sebagaimana vicarious liability dan identification, kejahatan yang dilakukan korporasi juga merupakan tanggung jawab individu-individu di dalamnya. Demikian juga, korporasi bertanggung jawab atas kejahatan yang dilakukan oleh individu-individunya. Jika suatu korporasi dikenai suatu hukuman atas kejahatan, kepada siapa hukuman tersebut akan dikenakan? Jawaban yang masuk akal adalah direktur perusahaan.

Menurut identification, tanggung jawab perusahaan sering didasarkan atas kejahatan yang dilakukan direktur atau para eksekutifnya. Sayangnya, hal itu akan terlihat sangat tidak adil bagi direktur yang selalu menjalankan bisnisnya sesuai dengan hukum yang berlaku. Oleh karena itu diperlukan adanya keseimbangan tanggung jawab terhadap kejahatan korporasi dari direktur, eksekutif, manajer, dan karyawan. Setiap individu harus bertanggung jawab baik secara moral maupun hukum atas keputusan dan tindakan mereka. Jika seseorang melakukan tindakan kejahatna melalui perusahaan, maka tuntutan hukum seharusnya dikenakan terhadap orang tersebut, bukan terhadap perusahaan, terutama jika tindakan kejahatan tersebut tidak memberikan keuntungan terhadap perusahaan. Perusahaan bertindak melalui individu tetapi individu juga bertindak melalui perusahaan. Oleh karena itu, tanggung jawab atas suatu tindakan kejahatan yang dilakuakan individu seharusnya tidak dilimpahkan kepada perusahaan. Begitu juga sebaliknya.

Pertanggungjawaban pidananya ditempatkan di luar KUHP agar dapat mengakomodir pengaturan seperti tersebut di atas, dan tentu saja dengan tetap mengacu pada KUHP sebagai pedoman umum. Beberapa peraturan perundang-undangan di luar KUHP telah menentukan korporasi sebagai subjek tindak pidana, sehingga penuntutan dan penjatuhan pidana dapat dilakukan kepada korporasi. Beberapa peraturan perundang-undangan tersebut antara lain, Undang-Undang No. 7 Drt Tahun 1955 tentang Tindak Pidana Ekonomi, Undang-Undang No. 8 Tahun 1995 tentang Pasar Modal, UndangUndang No. 5 Tahun 1997 tentang Psikotropika, Undang-Undang No. 22 Tahun 1997 tentang Narkotika, Undang-Undang No. 23 Tahun 1997 tentang Pengelolaan Lingkungan Hidup, UndangUndang No. 5 Tahun 1999 tentang Larangan Monopoli dan Persaingan Usaha Tidak Sehat, UndangUndang No. 8 Tahun 1999 tentang Perlindungan Konsumen, Undang-Undang No. 31 Tahun 1999 tentang Pemberantasan Tindak Pidana Korupsi sebagaimana telah diubah dengan Undang-Undang No. 20 Tahun 2001, Undang-Undang No. 15 Tahun 2002 tentang Tindak Pidana Pencucian Uang 
sebagaimana telah diubah dengan Undang-Undang No. 8 Tahun 2010 tentang Pencegahan Dan Pemberantasan Tindak Pidana Pencucian Uang. Peraturan perundang-undangan tersebut di atas telah menentukan korporasi tersebut sebagai subjek tindak pidana.

Namun demikian, apakah formulasi ketentuan-ketentuan di dalamnya telah dapat dijadikan dasar bagi pembebanan pertanggungjawaban pidana kepada korporasi, terutama pertanggungjawaban korporasi terhadap korban kejahatan korporasi. Formulasi pertanggungjawaban pidana korporasi tentu saja tidak cukup hanya dengan menyebutkan korporasi sebagai subjek tindak pidana saja, melainkan juga harus menentukan aturan mengenai sistem pidana dan pemidanaannya, sehingga diperlukan sebuah upaya reorientasi dan reformulasi pertanggungjawaban pidana terhadap korban kejahatan korporasi di masa yang akan datang.

Reorientasi dan reformulasi pertanggungjawaban pidana terhadap korban kejahatan korporasi antara lain meliputi ketentuan mengenai: (1) ketentuan mengenai kapan suatu tindak pidana dapat dikatakan sebagai tindak pidana yang dilakukan oleh korporasi; (2) siapa yang dapat dituntut dan dijatuhi pidana atas kejahatan yang dilakukan korporasi; (3) jenis-jenis sanksi yang sesuai dengan subjek tindak pidana berupa korporasi yang berorientasi pada pemberian ganti kerugian kepada korban.

Formulasi mengenai ketentuan tersebut harus diatur secara tegas untuk meminimalisir kemungkinan korporasi melepaskan diri dari tanggungjawab atas kejahatan yang dilakukannya. Mustahil memberikan pemenuhan ganti kerugian yang diderita oleh korban oleh korporasi, apabila korporasi yang dimaksud tidak dapat dijerat, dituntut, dan dijatuhi pidana berdasarkan peraturan perundangundangan yang ada.

\section{Tindak Pidana yang Dilakukan oleh Korporasi}

Korporasi sebagai subjek tindak pidana perumusannya berada dalam peraturan perundangundangan di luar KUHP, maka langkah selanjutnya dalam membebankan pertanggungjawaban pidana kepada korporasi adalah dengan menentukan aturan atau syarat mengenai kapan suatu korporasi dikatakan melakukan tindak pidana. Dengan kata lain, harus ditentukan pedoman atau batasan suatu tindak pidana dapat dilakukan oleh korporasi. Dalam Undang-Undang No. 31 Tahun 1999 Jo. Undang-Undang No. 20 Tahun 2001 tentang Pemberantasan Tindak Pidana Korupsi, khususnya Pasal 20 ayat (2) ditentukan bahwa: "Tindak pidana korupsi dilakukan oleh korporasi apabila tindak pidana tersebut dilakukan oleh orang-orang baik berdasarkan hubungan kerja maupun berdasarkan hubungan lain, bertindak dalam lingkungan korporasi tersebut baik sendiri maupun bersama-sama.”

Berdasarkan ketentuan tersebut, suatu tindak pidana dikatakan dapat dilakukan oleh korporasi apabila berdasarkan hubungan kerja atau hubungan lain, dan dalam lingkungan korporasi. Syarat berupa "berdasarkan hubungan lain" tersebut masih terlalu luas, karena bisa saja orang yang tidak mempunyai hubungan kerja langsung dengan korporasi, dapat menyebabkan korporasi ikut bertanggungjawab atas tindak pidana yang dilakukannya. Oleh karena itu, sebaiknya formulasi tersebut dibatasi pada orang-orang atau mereka yang mempunyai hubungan langsung dengan korporasi saja yang dapat melibatkan korporasi untuk ikut bertanggungjawab atas tindak pidana yang dilakukannya. Formulasi semacam itu dapat ditemukan pada Undang-Undang No. 15 tahun 2002 Jo. Undang-Undang No. 8 Tahun 2010 tentang Pencegahan Dan Pemberantasan Tindak Pidana Pencucian Uang, dimana dalam Pasal 6 ayat (1) ditentukan bahwa Dalam hal tindak pidana Pencucian Uang sebagaimana dimaksud dalam Pasal 3, Pasal 4, dan Pasal 5 dilakukan oleh Korporasi, pidana dijatuhkan terhadap Korporasi dan/atau Personil Pengendali Korporasi.. Lebih lanjut dalam Pasal 6 ayat (2) Undang-Undang tentang Pencegahan Dan Pemberantasan Tindak Pidana Pencucian Uang : "Pidana dijatuhkan terhadap Korporasi apabila tindak pidana Pencucian Uang ; a. dilakukan atau diperintahkan oleh Personil Pengendali Korporasi; b. dilakukan dalam rangka pemenuhan maksud dan tujuan Korporasi; c. dilakukan sesuai dengan tugas dan fungsi pelaku atau pemberi perintah; dan d. 
dilakukan dengan maksud memberikan manfaat bagi Korporasi.” Dengan kata lain, korporasi dapat dipertanggungjawabkan secara pidana hanya apabila tindak pidana yang dilakukan pengurus tersebut, adalah kegiatan yang termasuk dalam lingkup usaha korporasi.

Formulasi ketentuan-ketentuan tersebut telah jelas menentukan kapan suatu tindak pidana dapat dikatakan sebagai tindak pidana yang dilakukan oleh korporasi. Ada pedoman atau batasan yang jelas mengenai kapan suatu tindak pidana dilakukan oleh korporasi, sehingga apabila batasan tesebut terpenuhi maka korporasi dapat dikatakan telah melakukan tindak pidana yang dimaksud, dan kepadanya dapat dilakukan penuntutan dan penjatuhan pidana atas kejahatan yang dilakukannya.

Peraturan perundang-undangan yang telah disebut sebelumnya telah memberikan pedoman atau batasan mengenai kapan suatu tindak pidana dilakukan oleh korporasi, bagaimana dengan peraturan perundang-undangan di luar KUHP lainnya, apakah juga telah menentukan pedoman atau batasan tersebut. Setelah diteliti, ternyata tidak semua peraturan perundang-undangan di luar KUHP memberikan pedoman atau batasan mengenai kapan tindak pidana dilakukan oleh korporasi. Peraturan perundangan-undangan di luar KUHP yang tidak memberikan pedoman atau batasan tersebut misalnya : Undang-Undang No. 6 Tahun 1984 tentang Pos, Undang-Undang No. 5 Tahun 1997 tentang Psikotropika, Undang-Undang No. 22 Tahun 1997 tentang Narkotika, Undang-Undang No. 23 Tahun 1997 tentang Pengelolaan Lingkungan Hidup, Undang-Undang No. 5 Tahun 1999 tentang Larangan Monopoli dan Persaingan Usaha Tidak Sehat, Undang-Undang No. 8 Tahun 1999 tentang Perlindungan Konsumen.

Peraturan perundang-undangan tersebut menunjukkan ketidakseragaman peraturan perundangundangan di luar KUHP dalam menentukan batasan mengenai kapan suatu tindak pidana dapat dikatakan sebagai tindak pidana yang dilakukan oleh korporasi. Hal ini merupakan suatu wujud kelemahan formulasi peraturan perundang-undangan terutama yang berkaitan dengan pertanggungjawaban pidana korporasi terhadap korban kejahatan korporasi, karena kelemahan ini akan menjadi faktor penghambat dalam penerapan atau aplikasi dan juga eksekusi dari peraturan perundang-undangan tersebut. Diperlukan reorientasi dan reformulasi dari peraturan perundangundangan yang berkaitan dengan pedoman atau batasan mengenai kapan suatu tindak pidana dapat dikatakan dilakukan oleh korporasi. Peraturan perundang-undangan yang belum menentukan kapan suatu korporasi melakukan tindak pidana dapat mengadopsi dari formulasi peraturan perundangundangan yang telah mengatur, misalnya, Undang-Undang Pemberantasan Tindak Pidana Korupsi dan UndangUndang Pencegahan Dan Pemberantasan Tindak Pidana Pencucian Uang. Dengan demikian, korporasi yang melakukan kejahatan dan memenuhi batasan mengenai kapan korporasi dapat dikatakan melakukan tindak pidana, dapat dibebani pertanggungjawaban pidana, khususnya pertanggungjawaban pidana korporasi terhadap korban kejahatan korporasi.

\section{Siapa yang Dapat Dituntut dan Dijatuhi Pidana Atas Kejahatan yang Dilakukan Korporasi}

Perihal siapa yang dapat dipertanggungjawabkan atas kejahatan yang dilakukan oleh korporasi adalah sangat penting, karena hal ini sangat erat kaitannya dengan pertanggungjawaban pidana atas kejahatan yang dilakukan oleh korporasi. Apabila telah dapat diidentifikasi siapa yang bertanggungjawab atas kejahatan yang dilakukan oleh korporasi, maka penuntutan dan penjatuhan pidana dapat dilakukan kepada mereka yang dapat dipertanggungjawabkan tersebut.

Dalam Undang-Undang Tindak Pidana Ekonomi khususnya pada Pasal 15 ayat (1) telah ditentukan bahwa apabila korporasi melakukan tindak pidana, maka yang dapat dituntut dan dijatuhi pidana dan tindakan tata tertib adalah korporasi itu sendiri, yang memberikan perintah melakukan tindak pidana, atau kedua-duanya (korporasi dan yang memberi perintah). Undang-Undang No. 23 Tahun 1997 tentang Pengelolaan Lingkungan Hidup dalam Pasal 46 ayat (1) dan (2) secara garis besar menentukan bahwa yang dapat dibebani pertanggungjawaban pidana adalah: (1) korporasi atau badan hukum, perseroan, perserikatan, yayasan atau organisasi lain tersebut; (2) mereka yang memberi 
perintah untuk melakukan tindak pidana; (3) atau kedua-keduanya, yaitu korporasi dan mereka yang memberi perintah melakukan tindak pidana.

Undang-Undang No. 31 Tahun 1999 Jo. Undang-Undang No. 20 Tahun 2001 tentang Pemberantasan Tindak Pidana Korupsi dalam Pasal 20 ayat (1) menetukan bahwa tuntutan dan penjatuhan pidana dapat dikenakan terhadap korporasi, pengurus korporasi, atau kedua-duanya. Sedangkan dalam Undang-Undang No. 8 tahun 2010 tentang Pencegahan Dan Pemberantasan Tindak Pidana Pencucian Uang Pasal 6 ayat (1) ditentukan bahwa penjatuhan pidana dapat dilakukan terhadap pengurus dan/atau kuasa pengurus, maupun korporasi itu sendiri. Ketentuan mengenai siapa yang dapat dituntut dan dijatuhi pidana atas kejahatan yang dilakukan korporasi ternyata tidak diatur dalam beberapa peraturan perundang-undangan di luar KUHP lainnya. Peraturan perundang-undangan tersebut misalnya: Undang-Undang No. 5 Tahun 1997 tentang Psikotropika, Undang-Undang No. 22 Tahun 1997 tentang Narkotika, Undang-Undang No. 23 Tahun 1997 tentang Pengelolaan Lingkungan Hidup, Undang-Undang No. 5 Tahun 1999 tentang Larangan Monopoli dan Persaingan Usaha Tidak Sehat, Undang-Undang No. 8 Tahun 1999 tentang Perlindungan Konsumen.

Tidak diaturnya ketentuan mengenai siapa yang dapat dituntut dan dijatuhi pidana atas kejahatan yang dilakukan oleh korporasi dalam beberapa peraturan perundang-undangan di luar KUHP merupakan suatu ketidakkonsistenan dari para pembuat undang-undang yang dapat menjadi faktor penghambat bagi tahap-tahap selanjutnya, yaitu tahap aplikasi dan tahap eksekusi. Oleh karena itu diperlukan reorientasi dan reformulasi atas peraturan perundang-undangan tersebut, hal ini penting mengingat tahap formulasi merupakan tahap paling strategis dalam upaya pencegahan dan penanggulangan kejahatan. Reformulasi yang dimaksud adalah reformulasi yang berkaitan dengan ketentuan mengenai siapa yang dapat dibebani pertanggungjawaban pidana atau yang dapat dutuntut dan dijatuhi pidana. Peraturan perundang-undangan di luar KUHP yang belum mengatur hal tersebut dapat mengadopsi formulasi ketentuan dalam peraturan perundang-undangan yang telah menentukan siapa yang dapat dibebani pertanggungjawaban pidana atas kejahatan yang dilakukan oleh korporasi.

Dengan reorientasi dan reformulasi tersebut, maka akan tercipta suatu keseragaman pedoman atau aturan dalam peraturan perundang-undangan di luar KUHP yang berkaitan dengan pembebanan pertanggung jawaban pidana atas kejahatan korporasi, terutama dalam rangka pengaturan mengenai pertanggung jawaban pidana korporasi terhadap korban kejahatan korporasi.

\section{Jenis-Jenis Sanksi yang Sesuai Dengan Subjek Tindak Pidana}

Bagian akhir berkaitan denga model pertanggungjawaban pidana korporasi terhadap korban kejahatan korporasi adalah berkaitan dengan jenis-jenis sanksi yang dapat dijatuhkan kepada korporasi. Tahap ini merupakan tahap yang paling substansial, karena pada tahap inilah letak reorientasi dan reformulasi pertanggungjawaban pidana korporasi terhadap korban kejahatan korporasi yang sebenarnya. Hal ini dimungkinkan karena pada tahap inilah akan direorientasi dan direformulasi ketentuan mengenai jenis-jenis sanksi bagi korporasi dalam upaya memberikan suatu bentuk ganti kerugian kepada korban kejahatan korporasi, sebagai wujud pertanggungjawaban pidana korporasi kepada korban kejahatan korporasi.

Setelah dilakukan penelitian terhadap peraturan perundang-undangan di luar KUHP, didapatkan hasil berkaitan dengan jenis sanksi yang dapat dijatuhkan kepada korporasi atas kejahatan yang dilakukannya. Sanksi-sanksi tersebut berupa pidana denda, pidana tambahan, dan tindakan tata tertib. Ketiga sanksi tersebut merupakan jenis-jenis sanksi yang dapat diancamkan kepda korporasi sehubungan dengan sifat korporasi sebagai subjek tindak pidana yang berbeda dengan subjek tindak pidana berupa manusia atau orang perorangan. Ada sanksi pidana yang diterapkan kepada subjek tindak pidana berupa orang yang tidak dapat diterapkan kepada korporasi, misalnya penjara atau kurungan. 


\section{Pidana Denda}

Dari beberpa peraturan perundang-undangan yang diteliti, ternyata semua mencantumkan pidana denda sebagai pidana pokok yang dapat dijatuhkan kepada korporasi, misalnya: (1) UndangUndang No. 5 Tahun 1997 tentang Psikotropika menentukan bahwa pidana denda yang dapat dijatuhkan kepada korporasi adalah berupa pidana denda sebesar 2 (dua) kali yang diancamkan; (2) Undang-Undang No. 23 Tahun 1997 tentang Pengelolaan Lingkungan Hidup, pada Pasal 45 ditentukan bahwa pidana yang dapat dijatuhkan kepada korporasi adalah pidana denda dengan diperberat sepertiga; (3) Undang-Undang No. 31 Tahun 1999 Jo. Undang-Undang No. 20 Tahun 2001 tentang Pemberantasan Tindak Pidana Korupsi, pada Pasal 20 ayat (7) ditentukan bahwa pidana pokok yang dapat dijatuhkan kepada korporasi adalah pidana denda dengan ketentuan maksimum pidana ditambah dengan sepertiga (1/3); (4) Undang-Undang No. 8 tahun 2010 tentang Pencegahan dan Pemberantasan Tindak Pidana Pencucian Uang, pada Pasal 7 ayat (1) dimana ditentukan pidana pokok bagi korporasi adalah adalah pidana denda paling banyak Rp100.000.000.000,00 (seratus miliar rupiah).

Peraturan perundang-undangan di luar KUHP menentukan pidana denda sebagai pidana yang dapat dijatuhkan kepada korporasi yang melakukan tindak pidana, yang menjadi masalah kemudian adalah, apakah ketentuan penjatuhan pidana denda tersebut telah diikuti oleh aturan mengenai pidana pengganti denda apabila denda yang dijatuhkan tidak dibayarkan oleh korporasi. Demikian juga mengenai pidana tambahan berupa pembayaran ganti kerugian, tidak ada ketentuan yang mengatur mengenai alternatif apabila pembayaran ganti kerugian tersebut tidak dilaksanakan oleh korporasi.

Formulasi yang tidak tuntas seperti yang dikemukakan di atas tentu akan memberikan dampak berupa tidak adanya ketentuan atau aturan yang dapat memaksa korporasi yang tidak mau membayar denda atau melaksanakan pembayaran ganti kerugian. Seharusnya ditetapkan ketentuan yang mengatur pidana pengganti denda maupun pidana tambahan berupa pembayaran ganti kerugian, misalnya pencabutan izin usaha korporasi atau bahkan pembubaran korporasi yang diikuti likuidasi sebagaimana diterapkan dalam Undang-Undang No. 8 tahun 2010 tentang Pencegahan dan Pemberantasan Tindak Pidana Pencucian Uang.

\section{Pidana Tambahan}

Selain pidana denda, peraturan perundang-undangan pidana di luar KUHP juga mengenal adanya pidana tambahan yang juga dapat dikenakan kepada koporasi. Pengaturan mengenai pidana tambahan tersebut antara lain terdapat dalam beberapa peraturan perundang-undangan berikut ini:

1. Undang-Undang No. 7 Drt Tahun 1955 tentang Tindak Pidana Ekonomi, pada pasal 7 mengenai pidana tambahan berupa, penutupan seluruhnya atau sebagian perusahaan si terpidana, perampasan barang tidak tetap yang berwujud maupun tidak berwujud termasuk perusahaan si terpidana yang diperoleh dari tindak pidana ekonomi, pencabutan seluruh atau sebagian hak-hak tertentu atau penghapusan seluruh atau sebagian keuntungan tertentu, yang telah atau dapat diberikan kepada si terpidana oleh Pemerintah berhubung dengan perusahaannya, untuk waktu selama-lamanya dua tahun, dan sanksi berupa pengumuman putusan hakim.

2. Undang-Undang No. 5 Tahun 1997 tentang Psikotropika, pada Pasal 70 mengenai pidana tambahan yang dapat dijatuhkan kepada korporasi berupa pencabutan izin usaha.

3. Undang-Undang No. 22 Tahun 1997 tentang Narkotika, pada Pasal 91 mengenai pidana tambahan, berupa pencabutan hak sesuai dengan peraturan perundang-undangan yang berlaku, tidak diatur secara eksplisit mengenai pidana tambahan yang dapat dijatuhkan kepada korporasi.

4. Undang-Undang No. 23 Tahun 1997 tentang Pengelolaan Lingkungan Hidup, dalam perumusan pidana tambahan tidak diatur secara eksplisit, akan tetapi di masukkan kedalam kategori tindakan tata tertib sebagaimana diatur dalam Pasal 47. Walaupun demikian, jenis tindakan tata tertib berupa perampasan keuntungan dan penutupan perusahaan yang diatur dalam Pasal 47, 
pada hakikatnya merupakan jenis pidana tambahan jika mengacu pada Pasal 10 huruf b KUHP mengenai jenis-jenis pidana tambahan.

5. $\quad$ Undang-Undang No. 5 Tahun 1999 tentang Larangan Praktek Monopoli Dan Persaingan Usaha Tidak Sehat, dalam Pasal 49 diatur mengenai pidana tambahan berupa pencabutan izin usaha, larangan kepada pelaku usaha yang telah terbukti melakukan pelanggaran terhadap undangundang ini untuk menduduki jabatan direksi atau komisaris sekurang-kurangnya 2 (dua) tahun dan selam-lamanya 5 (lima) tahun, atau penghentian kegiatan atau tindakan tertentu yang menyebabkan timbulnya kerugian pada pihak lain.

6. Undang-Undang No. 8 Tahun 1999 tentang Perlindungan Konsumen, pada Pasal 63 tentang pidana tambahan berupa perampasan barang tertentu, pengunguman keputusan hakim, pembayaran ganti rugi, perintah penghentian kegiatan tertentu yang menyebabkan timbulnya kerugian konsumen, kewajiban penarikan barang dari peredaran, atau pencabutan izin usaha.

7. Undang-Undang No. 8 tahun 2010 tentang Pencegahan dan Pemberantasan Tindak Pidana Pencucian Uang, pada Pasal 7 ayat (2) ditentukan bahwa selain pidana denda, terhadap korporasi juga dapat dijatuhkan pidana tambahan berupa pencabutan izin usaha dan/atau pembubaran korporasi yang diikuti dengan likuidasi.

Formulasi berupa perumusan penjatuhan pidana tambahan yang tidak eksplisit berupa pencabutan hak sesuai peraturan perundang-undangan yang berlaku harus direformulasi mengingat kelamahan tersebut dapat menghambat pengaplikasian ketentuan tersebut. Sebagai contoh, ketentuan dalam Pasal 91 Undang-Undang No 22 Tahun 1997 tentang Narkotika, dimana ditentukan bahwa penjatuhan pidana terhadap segala tindak pidana narkotika dapat juga dijatuhkan pidana tambahan berupa pencabutan hak sesuai dengan peraturan perundang-undangan yang berlaku. Lebih lanjut dalam penjelasan Pasal 91 ditentukan bahwa peraturan perundang-undangan yang dimaksud adalah Pasal 35 ayat (1) butir 1, 2, dan 6 KUHP. Pencabutan yang dimaksud dalam penjelasan tersebut berupa hak memegang jabatan, hak memasuki Angkatan Bersenjata dan hak menjalankan pencaharian yang tertentu. Jenis pidana tambahan tersebut jelas tidak dapat diterapkan kepada korporasi. Oleh karena itu, sebaiknya penyebutan pidana tambahan harus diatur secara tegas, misalnya berupa pencabutan izin usaha.

\section{Tindakan Tata Tertib}

Jenis sanksi lain yang dapat dijatuhkan kepada korporasi dalam peraturan perundangundangan di luar KUHP adalah berupa tindakan tata tertib. Sanki berupa tindakan tata tertib tersebut dapat ditemukan dalam beberapa peraturanperundang- undangan di luar KUHP, antara lain dalam: (1) Undang-Undang No. 7 Drt Tahun 1955 tentang Tindak Pidana Ekonomi, pada Pasal 8 mengenai tindakan tata tertib berupa, menempatkan si terpidana di bawah pengampuan, mewajibkan pembayaran uang jaminan, mewajibkan membayar sejumlah uang sebagai pencabutan keuntungan, mewajibkan mengerjakan apa yang dilalaikan tanpa hak, meniadakan apa yang dilakukan tanpa hak, dan melakukan jasa-jasa untuk memperbaiki akibat-akibat satu sama lain, semua atas biaya si terpidana. (2) Undang-Undang No. 23 Tahun 1997 tentang Pengelolaan Lingkungan Hidup, pada Pasal 47 mengenai tindakan tata tertib yang dapat dikenakan kepada korporasi berupa perampasan keuntungan yang diperoleh dari tindak pidana, penutupan perusahaan baik sebagian maupun seluruhnya, perbaikan akibat tindak pidana, mewajibkan mengerjakan apa yang dilakukan tanpa hak, meniadakan apa yang dilalaikan tanpa hak, dan/atau menempatkan perusahaan dibawah pengampuan paling lama 3 (tiga) tahun.

Dengan mengacu pada kelemahan-kelemahan tersebut diatas, maka sekiranya dapat diperoleh gambaran-gambaran yang dapat digunakan dalam menentukan kebijakan formulasi pertanggungjawaban pidana korporasi terhadap korban kejahatan korporasi di masa yang akan datang, khususnya mengenai jenis-jenis sanksi pidana yang dapat dijatuhkan kepada korporasi. 
Berbicara mengenai reorientasi dan reformulasi jenis sanksi yang dapat dijatuhkan kepada korporasi tidak bisa dilepaskan dari konsep atau rancangan KUHP itu sendiri. Jenis pidana dalam Konsep KUHP 2006 terdapat dalam Pasal 65, ditentukan bahwa pidana pokok terdiri atas pidana penjara, pidana tutupan, pidana pengawasan, pidana denda, dan pidana kerja sosial. Lebih lanjut dalam Pasal 67, diatur mengenai pidana tambahan yang terdiri atas pencabutan hak tertentu, perampasan barang tertentu dan/atau tagihan, pengumuman putusan hakim, pembayaran ganti kerugian, dan pemenuhan kewajiban adat setempat dan/atau kewajiban menurut hukum yang hidup dalam masyarakat.

Dalam Konsep KUHP 2006, pidana pokok yang dapat dijatuhkan kepada korporasi adalah pidana denda. Dalam Pasal 80 ayat (4) ditentukan bahwa pidana denda paling banyak untuk korporasi adalah kategori lebih tinggi berikutnya. Dalam ayat (5) diatur mengenai kategori pidana denda yaitu: kategori I Rp 1.500.000,00 (satu juta lima ratus ribu rupiah); kategori II Rp 7.500.000,00 (tujuh juta lima ratus ribu rupiah); kategori III Rp 30.000.000,00 (tiga puluh juta rupiah); kategori IV Rp 75.000.000,00 (tujuh puluh lima juta rupiah); kategori V Rp 300.000.000,00 (tiga ratus juta rupiah); dan kategori VI Rp 3.000.000.000,00 (tiga miliar rupiah).

Lebih lanjut dalam Pasal 80 ayat (5) diatur mengenai kategori pidana denda paling banyak bagi korporasi yang melakukan tindak pidana yang diancamkan, yaitu: (1) pidana penjara paling lama 7 (tujuh) tahun sampai dengan 15 (lima belas) tahun adalah pidana denda Kategori V; (2) pidana mati, pidana penjara seumur hidup, atau pidana penjara paling lama 20 (dua puluh) tahun adalah pidana denda Kategori VI.

Pidana denda paling sedikit untuk korporasi sebagaimana dimaksud pada ayat (5) adalah pidana denda Kategori IV. Konsep juga telah mengatur mengenai pidana pengganti denda bagi korporasi yang tidak melaksanakan pembayaran denda, sebagaimana diatur dalam Pasal 85, ditentukan bahwa jika pengambilan kekayaan atau pendapatan sebagaimana dimaksud dalam Pasal 82 ayat (2) tidak dapat dilakukan, maka untuk korporasi dikenakan pidana pengganti berupa pencabutan izin usaha atau pembubaran korporasi. Berkaitan dengan pidana tambahan berupa pencabutan hak bagi korporasi, Pasal 91 ayat (2) menentukan bahwa hak yang dicabut adalah segala hak yang diperoleh korporasi.

Secara keseluruhan, jenis sanksi pidana yang terdapat dalam Konsep KUHP 2006 masih berorientasi pada pelaku tindak pidana, namun tidak dapat dipungkiri bahwa Konsep KUHP 2006 juga telah mulai memperhatikan korban, misalnya dengan adanya pidana pengawasan yang menetapkan syarat-syarat sebagaimana diatur dalam Pasal 78 ayat (3), dimana ditentukan bahwa, dalam penjatuhan pidana pengawasan dapat ditetapkan syarat : (1) terpidana tidak akan melakukan tindak pidana; (2) terpidana dalam waktu tertentu yang lebih pendek dari masa pidana pengawasan, harus mengganti seluruh atau sebagian kerugian yang timbul oleh tindak pidana yang dilakukan; dan/ atau (3) terpidana harus melakukan perbuatan atau tidak melakukan perbuatan tertentu, tanpa mengurangi kemerdekaan beragama dan kemerdekaan berpolitik.

Terkait dengan korporasi sebagai subjek tindak pidana, maka ketentuan mengenai pidana pengawasan tidak dapat diterapkan, karena pidana pengawasan yang diatur dalam Konsep KUHP 2006 ditujukan kepada orang dan bukan korporasi. Ketentuan tersebut diatur secara tegas dalam Pasal 77, ditentukan bahwa Terdakwa yang melakukan tindak pidana yang diancam dengan pidana penjara paling lama 7 (tujuh) tahun, dapat dijatuhi pidana pengawasan. Apabila para pembuat undang-undang memang menginginkan diaturnya korporasi sebagai subjek tindak pidana maka seharusnya juga dibuat perluasan dari ketentuan pidananya sehingga dapat diterapkan kepada korporasi. Misalnya pidana pengawasan, dapat pula diadopsi istilah asing yaitu corporate probation sebagaimana dikemukan oleh Gunter Heine berkaitan dengan Sanctions in the field of corporate criminal liability. 
Selain itu juga dalam Konsep KUHP 2006 sudah diatur mengenai pidana tambahan berupa pembayaran ganti kerugian sebagaimana diatur dalam Pasal 99, ditentukan bahwa: (1) dalam putusan hakim dapat ditetapkan kewajiban terpidana untuk melaksanakan pembayaran ganti kerugian kepada korban atau ahli warisnya; (2) jika kewajiban pembayaran ganti kerugian sebagaimana dimaksud pada ayat (1) tidak dilaksanakan, maka berlaku ketentuan pidana penjara pengganti untuk pidana denda. Dari ketentuan tersebut terlihat bahwa sudah ada ketentuan yang mengatur apabila kewajiban pembayaran denda tidak dilaksanakan, dapat diberlakukan ketentuan pidana penjara pengganti untuk pidana denda. Terkait dengan korporasi sebagai pelaku tindak pidana, maka perumusan seperti ini tidak dapat diterapkan kepada korporasi sebagai pelaku tindak pidana, karena pada ayat (2) ditentukan apabila pidana denda tidak dilaksanakan, maka berlaku ketentuan pidana penjara pengganti denda yang mustahil dijatuhkan kepada korporasi.

Secara keseluruhan, Konsep KUHP 2006 belum mengklasifikasikan atau mengatur secara tegas jenis-jenis pidana yang dapat diterapkan kepada subjek tindak pidana berupa orang dan jenisjenis pidana yang dapat diterapkan kepada subjek tindak pidana bukan orang (korporasi). Merupakan suatu hal yang penting untuk membedakan jenis-jenis pidana yang dapat diterapkan kepada orang dan jenis-jenis pidana yang dapat diterapkan kepada korporasi, agar supaya korporasi yang melakukan tindak pidana dapat dijatuhi pidana sesuai dengan kapasitasnya sebagai subjek tindak pidana bukan orang. Penulis berpendapat bahwa, perlu ada pemahaman bahwa dalam hukum pidana ada asas kulpabilitas, sehingga harus dibuktikan bahwa seseorang bisa dipidana apabila memang terbukti bersalah. Artinya tidak bisa secara otomatis sanksi pidana dialihkan dari corporate crime menjadi personal crime. Kesimpulannya secara umum seharusnya yang didakwa bukan hanya korporasi tetapi juga individu-individu yang bertanggungjawab terhadap peristiwa pidana yang terkait.

\section{SIMPULAN}

Pengertian Korporasi sudah harus dipahami secara sama oleh masyarakat, terutama oleh mereka yang terlibat langsung dalam penegakan hukum. Pada saat ini dalam konsep KUHP tahun 2006 memberikan pengertian korporasi dalam Pasal 182, yaitu: "Korporasi adalah kumpulan terorganisasi dari orang dan/atau kekayaan, baik yang merupakan badan hukum maupun bukan badan hukum”. Dengan diaturnya korporasi sebagai subjek tindak pidana dalam Konsep KUHP, maka diharapkan kelak aturan tersebut dapat menjadi pedoman bagi pengaturan korporasi sebagai subjek tindak pidana dalam peraturan perundang-undangan di luar KUHP. Merupakan suatu hal yang penting untuk membedakan jenis pidana yang dapat diterapkan kepada orang dan jenis-jenis pidana yang dapat diterapkan kepada korporasi, agar supaya korporasi yang melakukan tindak pidana dapat dijatuhi pidana sesuai dengan kapasitasnya sebagai subjek tindak pidana bukan orang, di mana secara umum yang didakwa bukan hanya korporasi tetapi juga individu-individu yang bertanggungjawab terhadap peristiwa pidana yang terkait.

\section{DAFTAR PUSTAKA}

Arief, B. N. (1998). Perbandingan hukum pidana. Jakarta: Raja Grafindo Persada.

Setiyono. (2003) Kejahatan korporasi analisis viktimologi dan pertanggungjawaban korporasi dalam hukum pidana Indonesia. Malang: Bayumedia.

Sjahdeini, S. R. (2007). Pertanggungjawaban pidana korporasi. Jakarta: Grafiti Pers. 